\title{
RECONSTRUCTING ENTREPRENEURIAL INTENTIONS TO IDENTIFY PREDISPOSITION FOR GROWTH
}

\begin{abstract}
The entrepreneurial-intentions literature largely ignores the a posteriori dichotomy of growthoriented and independence-oriented new ventures. We theorize that the 'individual-opportunity nexus' is embodied in the formation of entrepreneurial intention and drives the choice between growth- or independence-oriented new ventures. The orientation of the new venture will depend on the interaction of the salient outcomes offered by the opportunity and the attitudes the individual has /towards those outcomes, and by differences in entrepreneurial self-efficacy. We find that the attitude antecedents have opposite signs for growth compared to independence intentions, and suggest a means to identify intending entrepreneurs predisposed to growth.
\end{abstract}

\section{EXECUTIVE SUMMARY}

Researchers and observers of entrepreneurial new ventures distinguish between growthoriented and independence-oriented firms, and note that the latter contribute relatively little to societal benefit via employment creation and tax revenue generation. To increase social welfare it is important to identify individuals who are predisposed to manage growth-oriented firms, preferably at the earliest stage of the entrepreneurial process when entrepreneurial intentions are forming, and particularly if public funding is to be used to support new venture start-ups. Previously the study of entrepreneurial intention has been limited to the generic intention to start a new venture. This paper proposes that the entrepreneurial intention construct is currently too broad and can be made more useful by considering what type of new venture the individual intends to start. We argue that the growth intentions of the individual are embodied in the decision to start a new venture, and whether these are high-growth or low-growth intentions depends upon the abilities, attitudes, and means available to the individual, such that some intending entrepreneurs are predisposed to growing their venture whereas others are not. 
Our paper integrates a number of theoretical notions that are currently not well integrated into the intentions literature. First, we integrate the individual-opportunity nexus with heterogeneity on both sides of the nexus. We argue that growth-orientation of a new venture is intended by the individual due to interaction between that individual's attitudes and abilities and the new venture's supply of outcomes which are salient to the individual (namely income, autonomy, risk, work intensity, and work enjoyment). Since the individual typically has a choice among opportunities to pursue the individual must make a choice among these, which brings us to the second notion to be integrated - the choice of entrepreneurship as a career choice and the choice among entrepreneurial opportunities has been modeled as a utility-maximizing choice. We argue that the individual chooses the opportunity that provides the salient outcomes that best complement the individual's attitudes to those salient outcomes such that the individual forms the intention to start a specific new venture because that specific new venture opportunity allows the individual to maximize his/her expected well-being (or utility). The third issue we integrate into the intentions literature is that the a posteriori growth-oriented or independence-oriented nature of new ventures is an intended outcome except where subsequently thwarted by force majeure, being woven into the fabric of the new venture during the intentions stage of the entrepreneurial process. Finally, our theoretical model provides an explanation for the inconsistent and ambiguous findings relating to some of the human capital and cognitive antecedents of entrepreneurial intentions in previous studies when entrepreneurial intentions were defined too broadly to mean the simple intention to start a new venture without regard to the growth or independence intentions that are, we argue, necessarily embodied in the intention to start a new business venture. 
Thus we argue that intending entrepreneurs will choose to pursue the opportunity that offers them the combination of income, autonomy, risk, work effort and work enjoyment that maximizes their expected utility. We argue that these salient outcomes will be perceived by the intending entrepreneur to be different across opportunities and particularly for ventures with high-growth versus low-growth potential. We develop scales that measure the individual's intention to start either a growth-oriented or an independence-oriented new venture, and subsequently explain the strength of these intentions by the individual's attitudes to the salient outcomes, entrepreneurial self-efficacy, and control variables. We apply principal components analysis to espoused data provided by graduating MBA students (as proxies for intending entrepreneurs) and find that intentions for growth-oriented new ventures and independenceoriented new ventures are indeed separate and distinct constructs. ESE and control variables were estimated using pre-tested survey items, and attitudes to the salient outcomes were revealed by a conjoint experiment. We found that growth-oriented intentions (GOI) were positively and highly significantly associated with ESE; negatively and significantly associated with attitude to work enjoyment; and positively and marginally significantly associated with being male. Independence-oriented intentions (IOI) were negatively and significantly associated with risk tolerance; and positively but not significantly $(\mathrm{p}=0.125)$ associated with attitude to autonomy. Interestingly the signs for ESE, gender, and all of the attitude variables were opposite for growth-oriented intention as compared with independence-oriented intention. Thus we conclude that GOI and IOI are separate constructs; that they are driven by different antecedent variables, and that intending entrepreneurs may be identified as predisposed to growth (or not) on the basis of their attitudes and abilities. 


\section{INTRODUCTION}

The identification of individuals with entrepreneurial intentions is important because it facilitates private investment and public funding being most efficiently channeled toward those who will start new businesses that create value for individuals and society. There has been substantial research into the antecedent causes of the formation of entrepreneurial intentions, but previous authors have treated entrepreneurial intention as a single generic construct (Bird, 1988; Bird \& Jelinek, 1988; Krueger, 1993;

Krueger \& Brazeal, 1994; Krueger et al. 2000; Fitzsimmons \& Douglas, 2011; Lee et al. 2011), notwithstanding the general observation that entrepreneurs tend to subsequently operate one of two main types of new ventures - either an independence-oriented new venture or a growth-oriented new venture (Kolvereid, 1992; Wennekers \& Thurik, 1999; Reynolds, 2000; Gundry \& Welsch, 2001; Shaver et al. 2001; Carter et al. 2003; Gartner et al. 2004; Cassar, 2006, 2007; Hessels et al. 2008; and Shane, 2009). Since entrepreneurship is a planned activity (Ajzen, 1985; Krueger \& Carsrud, 1993) it seems plausible that intending entrepreneurs would incorporate into their planning that their venture would be growth-oriented, and/or would be an independence-oriented, to a greater or lesser degree. Accordingly, we suspect that the construct 'entrepreneurial intentions' is too broadly defined and lacks construct clarity (Suddaby, 2010) and thus potentially confounds prior research results.

Shane \& Venkataraman (2000; p.218) acknowledge the heterogeneity on both sides of the 'individual-opportunity nexus' and illuminate the critical issue when they say "The definition of an entrepreneur as a person who establishes a new organization is [problematic because it] does not include consideration of the wide variety of opportunities that different people identify... 
Consequently, empirical support for attributes... that differentiate entrepreneurs from other members of society is often questionable because these attributes confound the influence of opportunities and individuals". Similarly, Davidsson \& Wiklund (2001) argue that to understand entrepreneurial intentions one must consider both the characteristics of the individual and the organization in which they would work. Thus, studies of the antecedents of entrepreneurial intentions that neglect the heterogeneity on the opportunity side of the nexus are likely to confound the influence of opportunities and individuals, such that results attributable to individuals might also include the impact of the specific new venture opportunity envisioned. By considering the main dichotomy of new venture types on the opportunity side of the individual-opportunity nexus we hope to provide a better understanding of entrepreneurial intentions and better illuminate the public policy and educational implications of supporting nascent and fledgling entrepreneurs. Conversely, failing to consider heterogeneity of venture type in studies of entrepreneurial intention may cause public policy makers and educators to mentally homogenize entrepreneurs and inadvertently contribute to the failure rates of new ventures by encouraging the placement of 'square pegs into round holes' with consequent personal and societal losses.

Over the past few decades it has become conventional wisdom that governments should support new venture initiation. The basis for public financial support of nascent and fledgling entrepreneurs has been that most new job creation is by growth-oriented 'gazelles' that contribute disproportionately to employment growth and tax revenues (Birch, 1981; Storey, 1994). However several authors have pointed out that high-growth firms are relatively rare and the vast majority of new ventures are created primarily to provide 'salary-substitution' small businesses for their owners (Wennekers \& Thurik, 1999; Hessels et al. 2008; Shane, 2009). 
Shane (2009) argues that public support of salary-substitution new ventures is not an efficient use of public funds, and that funding policies should more-selectively identify those nascent entrepreneurs who are likely to establish high-growth businesses such that public funds are channeled to those most likely to use these in society's best interests. He suggests that screening mechanisms be applied to direct support to those who have higher potential for creating new jobs and generating tax revenue, rather than offering support to all start-up firms. He acknowledges that it is difficult to generalize on the likelihood of subsequent growth, but suggests that we should focus on the characteristics of the entrepreneurial opportunity as well as on the motivations and human capital of the nascent entrepreneur. This paper responds to that call.

The second main issue addressed in this paper is the incompleteness of our understanding of the process by which entrepreneurial intentions are formed and the underlying cognitive antecedents of entrepreneurial intentions. Researchers have argued that individuals form the intention to become entrepreneurs on the basis of the 'perceived desirability' and 'perceived feasibility' of the new venture opportunity envisioned (Krueger, 1993; Krueger \& Carsrud, 1993; Krueger \& Brazeal, 1994; Krueger et al. 2000). Perceived desirability refers to the personal appeal of entrepreneurial action and depends on the individual's attitudes to five salient outcomes of entrepreneurship, namely income, autonomy, risk, work effort, and other intrinsic costs and benefits, following Douglas \& Shepherd (2000, 2002). Lee et al. (2011) refer to these intrinsic costs and benefits as the job satisfaction associated with being self-employed and in this paper we will refer to them as 'work enjoyment'. Perceived feasibility refers to the individual's confidence that they can successfully complete relevant tasks. In the entrepreneurial context perceived feasibility is parsimoniously measured by 'entrepreneurial self-efficacy' (Bandura, 
1977; Boyd \& Vozikis, 1994; Chen et al. 1998; De Noble et al. 1999; Zhao et al. 2005: McGee et al. 2009).

But in these studies we often see inconsistent results for the attitudes to the salient outcomes used to proxy perceived desirability. Attitude to risk, for example, is sometimes significantly (e.g. Douglas \& Shepherd, 2002) and more often insignificantly (e.g. Brockhaus, 1980; Palich \& Bagby, 1995; Busenitz \& Barney, 1997; Fitzsimmons \& Douglas, 2011) related to entrepreneurship. But what if growth-oriented individuals react positively to risk (due to commensurately higher profits) while independence-oriented individuals react negatively? If so, the sign and significance of attitude to risk as an antecedent of generic entrepreneurial intentions would depend on the proportion of growth-oriented versus independence-oriented intending entrepreneurs in the sample. Further, we note that high entrepreneurial self-efficacy (ESE) is commonly found to be strongly associated with entrepreneurial intentions, but Fitzsimmons \& Douglas (2011) recently found that 'inevitable entrepreneurs' with low ESE nonetheless intend to start new businesses. If high ESE is a significant determinant of growth-oriented intentions, but is not significant for those contemplating (less complex) independence-oriented ventures, the effect size and significance of ESE as a determinant of generic entrepreneurial intentions will depend on the proportion of growth-oriented intending entrepreneurs in the sample.

Thus the first research question in this paper is whether the intention to become a growthoriented entrepreneur is a separate construct to the intention to become an independence-oriented entrepreneur, and thus whether some potential entrepreneurs are predisposed to the pursuit of growth while others are not. The second research question is whether the cognitive antecedents of these two subcategories of entrepreneurial intention are different - i.e. do growth-intending 
individuals have different cognitions regarding income, autonomy, risk and other salient outcomes of new ventures compared to independence-intending individuals? Thirdly, do ESE and other human capital factors (such as age, gender and prior education) impact differently on the two types of entrepreneurial intention? The final research question is whether we can identify, via these cognitive and human capital variables, those intending entrepreneurs who are predisposed to pursue growth as distinct from those who are not. By investigating these issues we make several important contributions to the entrepreneurial intentions literature.

In the following we first re-examine the intention-formation stage of the entrepreneurial process and explain how the individual-opportunity nexus, growth-orientation, and utilitymaximizing career choice are integrated into the formation of entrepreneurial intentions. We then develop hypotheses concerning the antecedents of the formation of intentions for each of the two main types of entrepreneurial new venture. Subsequently we describe our sample and method, before detailing the results of our empirical analysis. Finally we discuss the results and consider the implications for public policy, entrepreneurial education, and further research.

\section{THEORY DEVELOPMENT}

\subsection{Definitions}

For the purposes of this paper we define an 'entrepreneurial new venture' as a prospective and volitional new business firm that the individual might consider establishing to exploit an opportunity that is expected to create extrinsic and intrinsic benefits for that individual if not also for society at large. We propose that a person who is contemplating a non-employment and nonleisure occupation might consider self-employed entrepreneurship, and within that general 
occupation will consider launching a new venture that might be either highly growth-oriented, highly independence-oriented, or some other combination of growth and independence orientation. We envision a spectrum of growth intention ranging from extremely high to extremely low. Similarly we expect that independence intention will range from high to low, and that individuals will have both growth and independence intention but most will have one of these stronger than the other, with relatively few having moderate intentions towards both growth and independence.

It is important to discuss these intention concepts in further detail. We define growth intentions as the individual's intention to start a new venture that will be substantially larger in subsequent time periods. Growth of the firm will require profits initially or in prospect such that the entrepreneur can raise the capital necessary to grow the firm. In simple economic theory the profit-maximizing firm seeks growth up to the point where profits are maximized in the 'long run' with plant size being periodically adjusted upwards as sales grow (Thomas \& Maurice, 2011: p.477). As the firm matures, profits may precede growth, or growth may precede profits (Davidsson et al. 2009), or the firm may not grow much at all (Davidsson 1989) - but note that we are interested here in the a priori intentions of the individual for business growth (or not). Morris et al. (2005, p.270-1) state that the "growth model (requires) not only significant initial investment, but substantial re-investment in an attempt to grow the value of the firm to the point that it eventually generates a major capital gain for the initial investors". Growth ventures typically require the individual to take substantial risks in pursuit of the potential profitability (Knockaert et al. 2011), and would generally be expected by the individual to require decision making of higher order of difficulty (Covin \& Slevin, 1997), thus requiring greater management ability. Growth ventures are also probably expected by intending entrepreneurs to require greater 
work effort and to provide fewer intrinsic benefits of self-employment, as compared to independence-oriented ventures (Knockaert et al. 2011).

We define independence intention as the individual's intention to start a new venture that is primarily expected to allow the individual to 'be one's own boss' while providing an income sufficient to meet his/her needs and/or aspirations. One sub-type of independence-oriented new ventures has been called 'salary-substitute' new ventures (Shane, 2009) and includes “small firms that afford their owners a level of income similar to what they could earn in a conventional job. Examples... are dry cleaners, convenience stores, restaurants, accounting firms, retail stores and hairstyling salons" (Barringer \& Ireland, 2006, p.14). In a simple dichotomy of new venture types, 'independence-oriented' new ventures is necessarily a relatively broad category that would also include what Barringer and Ireland call 'lifestyle' ventures that allow pursuit of an individual's preferred leisure activity, hobby or avocation. "Lifestyle firms provide their... owners the opportunity to pursue a particular lifestyle and earn a living while doing so. Examples... include ski instructors, golf pros, and tour guides" (Barringer \& Ireland, 2006, p.14). Independence-oriented new ventures would also include 'subsistence ventures' (Morris et al. 2005) which enable the entrepreneur to earn enough income to survive while providing other intrinsic rewards of self-employment, including additional leisure time, effectively trading off income for these intrinsic rewards. Subsistence ventures may be part-time or full-time occupations and may involve hunting and gathering, offering personal services, or making items (e.g. souvenirs and artwork) for sale or barter. The primary trade-off for the independenceoriented entrepreneur seems to be that intrinsic rewards are substituted for the greater income that might have been earned elsewhere. These intrinsic rewards will typically include those 
flowing from a sense of independence and are also derived from job satisfaction (see, e.g. Steers et al. 2004; Lee et al. 2011; Lange, in press), risk avoidance, and work effort avoidance.

Other researchers have investigated the growth 'aspirations' of actual entrepreneurs (see, for example, Davidsson, 1989; Kolvereid, 1992; Cliff, 1998; Gundry \& Welsch, 2001; Wiklund \& Shepherd, 2003; Cassar, 2006, 2007; Dutta \& Thornhill, 2008; Knockaert et al. 2011). These studies use a variety of survey instruments to indicate practising entrepreneurs' intentions, preference, or willingness to grow. In light of these prior studies it is necessary here to distinguish between growth intentions of intending entrepreneurs and growth aspirations of practising entrepreneurs. While the growth aspirations of a practising entrepreneur are probably generally consistent with that person's prior growth intentions, practising entrepreneurs may need to modify their aspirations as a result of post-launch experience. Consider an intending entrepreneur with low-growth intentions whose new venture subsequently becomes highly profitable with high-growth potential, but does not grow due to the entrepreneur's aspirations to keep the operation small and manageable. This entrepreneur has several choices - he/she might (i) adjust his/her aspirations and manage a growing firm; or (ii) tolerate growth temporarily until a merger or asset sale can be arranged; or (iii) refuse to grow and simply maintain relatively high profitability as long as potential rivals are prevented from competing away this profitability. In our schema, which focuses on the pre-launch formation of entrepreneurial intentions, that individual did not have growth intentions as an intending entrepreneur and would more likely have had stronger independence intentions. As a second example, an intending entrepreneur with growth intentions may discover subsequently that sales growth does not eventuate and then might (i) continue trying to grow the firm; or (ii) revise downward his/her growth aspirations, perhaps ultimately adopting independence aspirations for that business venture, or (iii) close or 
sell that business and seek another business opportunity that better suits his/her growth intentions. In our schema this intending entrepreneur had growth intentions regardless of what his/her aspirations subsequently become.

Thus we clarify that an individual will form intentions in the 'exploration stage' of the entrepreneurial process, and these will transform into aspirations in the 'exploitation stage' of the entrepreneurial process (Choi \& Shepherd, 2004) after the launch of the new venture, and the firm that is observed going forward will be 'oriented' towards either growth or independence depending on the aspirations of the entrepreneur. In prospect, we expect that the growthintending individual will envision a choice set of potential new venture opportunities that each have relatively high potential for profits and growth, while the independence-intending individual will envision a set of new venture opportunities that tend to have relatively low profit and growth potential. Within these choice sets the individual will choose one opportunity to exploit and that one, we shall argue, will be the one that maximizes expected utility.

\subsection{The Formation of Entrepreneurial Intention}

To align with prior work we note that entrepreneurial action (McMullen \& Shepherd, 2006) occurs when three necessary conditions are fulfilled; namely the means, the motive, and the opportunity. The means are the human, social, financial and technological capital required to exploit the opportunity (see, e.g. Davidsson \& Honig, 2003); the motive is provided when the particular new venture is perceived to be the most desirable career option (see, e.g. Douglas \& Shepherd, 2000); and the opportunity is provided by the individual's perception of an un-served or under-served market need (see, e.g. Shane, 2000) or an under-utilized resource (Ardichvili et al. 2003). Building upon Baumol (1990) and Eisenhauer (1995), Douglas \& Shepherd (2000) 
argue that individuals will be motivated to start a new business venture if it promises them the greatest expected psychic satisfaction or 'utility'. Utility, or disutility, is derived from the salient outcomes offered by employment or self-employment situations. They argue that individuals derive utility from (and thus prefer to have more) income, autonomy, and other net perquisites, and conversely derive disutility from (and thus prefer to have less) risk exposure and work intensity. Since individuals are assumed to be self-serving and prefer greater total utility to less, individuals are expected to choose the career option that maximizes their total utility, which might be either an employment or a self-employment opportunity (Douglas \& Shepherd, 2000). In this paper we propose that the self-employment opportunity under consideration may be either growth-oriented or independence-oriented.

Preceding the decision to act entrepreneurially is the formation of entrepreneurial intention. In the context of the means, motive and opportunity pre-requisites for entrepreneurial action, entrepreneurial intention might form prior to the selection of a suitable opportunity (Fitzsimmons \& Douglas, 2011), and/or prior to the assembly of the necessary means (Stevenson, 1983). The entrepreneurial intentions literature (e.g. Krueger, 1993; Krueger \& Carsrud, 1993; Krueger \& Brazeal, 1994; Boyd \& Vozikis, 1994; Krueger et al. 2000; Zhao et al. 2005: Linan \& Chen, 2009; Thompson, 2009) has now largely agreed that entrepreneurial intention depends on two main antecedents, namely the perceived desirability (i.e. the motivation to exploit) and perceived feasibility (i.e. the sufficiency of means required to exploit) of a perceived opportunity, effectively assuming that a suitable opportunity has been identified previously. Perceived feasibility is effectively and parsimoniously measured by 'entrepreneurial self-efficacy' (Chen et al. 1998; De Noble et al. 1999; Boyd \& Vozikis, 1994; Krueger et al. 2000; Zhao et al. 2005: McGee et al. 2009), and perceived desirability has been measured by the individual's attitudes to 
incomes, to risk, to decision-making autonomy, (Krueger et al. 2000; Zhao et al. 2005: McGee et al. 2009). Fitzsimmons \& Douglas (2011) identified 'ownership of the firm' as a proxy for the psychological benefits associated with being one's own boss as their measure of perceived desirability, and Lee (2011) effectively considered job satisfaction as a proxy for the utility derived from working in one's own firm.

In Chart 1 we summarize our conceptual model of the process by which entrepreneurial intentions are formed. Following Shane \& Venkataraman (2000) we indicate that the characteristics of the new venture concept are determined by the interaction of the characteristics of the opportunity and the characteristics of the individual. The heterogeneity of the new venture has been categorized as by some authors as growth, independence, lifestyle and subsistence (e.g. Morris, et al., 2005; Barringer \& Ireland, 2006) while others have effectively collapsed the latter three types into an 'independence' type (e.g. Kolvereid, 1992; Reynolds, 2000; Shane, 2009) to provide a dichotomy of new venture types, which we will call growth-oriented and independence-oriented for simplicity. Although the latter group is a polyglot lot, our focus in this paper is on the growth-oriented new venture which seems to be a much less diverse category. We then argue that the individual will compare the focal opportunity with other accessible new venture opportunities and select the one that offers the greatest expected utility (Douglas \& Shepherd, 2000). If the chosen new venture opportunity offers more utility than the best available employment opportunity, the self-serving individual will be motivated to set up the new business venture, becoming a nascent entrepreneur at that point, and proceed toward launch and operation of the new venture as a practising entrepreneur.

[Chart 1 near here] 
To further clarify how the individual-opportunity nexus necessarily causes the individual to form either a growth intention and/or an independence intention within the intention to start a new venture, we need to examine the process of opportunity evaluation. We argue that each opportunity that is recognized or created is evaluated in terms of the salient outcomes that it seems to offer the individual, and when these are evaluated in conjunction with the individual's attitudes to each of these salient outcomes, one new venture will emerge as the utility maximizing one, and that one will be either a growth-oriented new venture, or an independenceoriented new venture, or something with aspects of both. To make this perfectly clear we are modeling (following Eisenhauer, 1995, and Douglas \& Shepherd, 2000) the individual's utility function as a linear additive function of five variables which we have called the salient outcomes of new venture action. Each outcome has an associated 'utility part-worth' that is the product of the quantum of the outcome supplied by the opportunity and the attitude of the individual toward that outcome, and these part-worths sum to equal the total utility that the individual expects to derive from that particular new venture opportunity, as shown in Chart 2.

\section{[Chart 2 near here]}

We stress that all intending entrepreneurs are expected to derive utility from income, autonomy, risk avoidance, work avoidance, and the remaining net benefits associated with ownership of their firm, which we call 'work enjoyment' in this paper. The heterogeneity of individuals means that they will have different attitudes (i.e. will appreciate more or less) the quantum of each salient outcome provided by any specific opportunity. Similarly the heterogeneity of opportunities means that different opportunities will supply different quanta of the salient outcomes. The individual's choice of the particular new venture to exploit is 
determined by the interaction of the salient outcomes provided by the opportunity and the individual's attitudes to each of the salient outcomes, and the opportunity chosen is the one that is expected to deliver the greatest expected total utility to the individual (rather than the utility expected from any single salient outcome - see Douglas \& Shepherd, 2000). Note that an individual with a strong positive attitude to income will not necessarily be growth intending, nor will an individual who has a strongly positive attitude to autonomy, or work enjoyment, for example, necessarily be independence-intending. Indeed, a growth-intending individual might gain greater utility from autonomy than does an independence-intending individual. It is the sum of the five part-worths that is determining, not any particular part-worth, as a large part-worth of one outcome might be easily outweighed by the combined effect of the other part-worths.

\section{HYPOTHESIS DEVELOPMENT}

\subsection{Theoretical Lens}

The theoretical model underlying our hypotheses is based on 'self-determination theory' (Deci \& Ryan, 1985, 2000; Gagne \& Deci, 2005) and 'person-environment fit' theory (Kristof, 1996; Cable \& Edwards, 2004; Kristof-Brown, Ryan, Zimmerman \& Johnson, 2005) which are both broadly consistent with the utility-maximizing theory of entrepreneurial behavior as utilized by Eisenhauer (1995) and Douglas \& Shepherd (2000). Self-determination theory (SDT) argues that individuals choose behaviors that serve three innate psychological needs and other situational needs. These innate psychological needs are the need for competence, the need for autonomy, and the need for relatedness (Deci \& Ryan, 1985). Situational needs are those that arise in the particular context (Gagne \& Deci, 2005) and in the context of the potential entrepreneur these can be summarized as the need for income, the need for risk avoidance, and 
the need for work avoidance. Person-environment (PE) fit theory considers "the compatibility between an individual and a work environment that occurs when their characteristics are well matched" (Kristof-Brown, et al. 2005, p.281) and argues that individuals will seek out and gravitate towards work situations that best provide the combination of outcomes that they are seeking. The PE fit model argues that individuals will derive greater job satisfaction in work contexts that provide the things (salient outcomes) that they appreciate, or conversely less of the things they do not appreciate, and has been utilized in the entrepreneurship literature previously by Markman \& Baron (2003); Leung et al. (2006); Brigham et al. (2007); and Lee et al. (2011).

\subsection{The Individual's Innate Need for Competence}

The individual's need for competence is similar to 'need for achievement' (McClelland 1961). Deci \& Ryan (1985) argue that individuals want to be 'good at' the actions they attempt, and thus choose actions that while challenging, are likely to result in successful outcomes because they believe the requirements of the task seem to lie within their realm of competence. In the entrepreneurship literature we know that entrepreneurial self-efficacy (ESE) reflects the confidence individuals have that they can successfully complete a series of entrepreneurial tasks (e.g. Chen et al. 1998; De Noble et al. 1999; McGee et al. 2009). ESE will reflect the prior education and business experience of the individual that relates to dealing with risk, making autonomous decisions, communicating with customers, dealing with suppliers, and so on. Since entrepreneurship in general involves challenging tasks we expect ESE to relate positively to the intention to be an entrepreneur due to individuals' innate need for competence, and indeed the dependence of entrepreneurial intentions on ESE has been well demonstrated by prior research. 
At issue here is whether ESE will have a differential impact on growth intentions vs. independence intentions.

It is proposed that while ESE will be a positive determinant of both intentions, it will be more important for the formation of growth intentions than for independence intentions. Intending entrepreneurs will envision the successful launch and survival of growth-oriented firms as requiring higher levels of human capital, particularly management acumen, as compared to the human capital needed to successfully launch an independence-oriented firm (Covin \& Slevin, 1997; Knockaert et al. 2011). Individuals with low ESE are expected to tend towards employment rather than self-employment, except for 'inevitable entrepreneurs' (Fitzsimmons \& Douglas, 2011) who have high perceived desirability (and low perceived feasibility) and are strongly motivated to be self-employed despite lacking the requisite competencies. The intending entrepreneur will expect greater management skills (such as risk recognition and mitigation, long-term strategy formulation, and marketing, human resource and financial management) to be required when he/she is expected to make substantial profits and to grow the firm in the future, rather than to make an acceptable level of profit while returning a range of non-monetary psychological benefits, other things being equal. In turn, managing an independence-oriented new venture would be perceived to require greater management skills than would being an employee of someone else. Accordingly, since ESE is a measure of the individual's confidence that they can successfully accomplish entrepreneurial tasks, and since individuals have an innate need for competence and therefore tend to take on challenges that they expect they can successfully achieve, we expect that ESE will be more strongly positively related to the intention to be a growth-oriented entrepreneur than to the intention to be an independence-oriented entrepreneur. This suggests the following hypotheses: 
Hla: $\quad$ ESE will be positively related to growth-oriented intentions;

H1b: $\quad$ ESE will be positively related to independence-oriented intentions;

H1c: ESE will be more positively related to growth-oriented intentions than to independence-oriented intentions.

\subsection{The Individual's Innate Need for Autonomy}

While previous research indicates that the individual's innate need for autonomy will be positively related to entrepreneurial intention, our concern here is whether there is a differential effect when two types of entrepreneurial intention are postulated. We argue that, in general, independence-oriented new ventures might be expected, a priori, to offer more autonomy than growth-oriented new ventures, other things being equal. The larger the firm the less decisionmaking autonomy the individual will expect to retain, since larger firms will have greater forces operating to constrain the manager's decision-making autonomy, such as the caveats and covenants of investors and bankers, the bargaining power of large customers and/or large suppliers, not to mention industrial relations issues with labor unions, regulation issues with the securities and exchange commission, workplace health and safety organizations, and finally the mutual-dependence recognized with rival firms. The lesser weight that we expect to be placed on income in the utility function of the independence-intending entrepreneur facilitates choice among a wider set of work hours, work locations, and working conditions for that person, as compared to the growth-intending entrepreneur. Thus we expect the independence-oriented type of new venture to appear (to the potential entrepreneur) to provide the greatest scope for decision-making autonomy, followed by the growth-oriented type, followed by the best available employment situation. This suggests the following hypotheses: 
H2a: Preference for autonomy will be positively related to growth-oriented intentions;

H2b: Preference for autonomy will be positively related to independence-oriented intentions;

H2c: Preference for autonomy will be more positively related to independence-oriented intentions than to growth-oriented intentions.

\subsection{The Individual's Innate Need for Relatedness}

'Relatedness' concerns the individual's need to relate to other individuals and groups, and to affiliate with and to engage in discourse and social interaction with others (Deci \& Ryan, 1985; Gagne \& Deci, 2005). In the context of the entrepreneurial process we expect the need for relatedness to be manifested in the desire to interact collegially with customers, suppliers, and co-workers in a satisfying way. In effect we are talking about the 'job satisfaction' construct from the organizational behavior literature (see, e.g. Steers et al. 2004) but see also Brockhaus (1980), Eisenhauer (1995), Lee et al. (2011) and Lange (in press) for discussion in the entrepreneurship context. Douglas \& Shepherd (2000) and more recently Fitzsimmons and Douglas (2011) considered the individual's attitude to the 'net perquisites' associated with business ownership. These intrinsic benefits (and costs) will be derived (and incurred) in the process of interaction with other managers, employees, suppliers, customers and investors associated with the work environment of the new venture. In this paper we use the construct 'work enjoyment' to be broadly consistent with Douglas \& Shepherd's (2000) 'net perquisites' and with Lee et al.'s (2011) 'job satisfaction' measures. Work enjoyment is the pleasure derived from one's working conditions and the interaction with co-workers, customers and suppliers, and correlates with job satisfaction (McMillan et al., 2003). Thus we intend work enjoyment to 
means the psychic utility derived from the interaction with co-workers, suppliers and customers and other intrinsic factors not already accounted for.

Arguably, some types of new venture will provide greater levels of work enjoyment than will others, for example by providing opportunities to interact with stakeholders in a lesscombative way, by providing a less-stressful work environment in which to interact, and/or by providing access to buyers or other stakeholders with whom the individual has greater affinity. We argue that the provision of work enjoyment is likely to be perceived (by the intending entrepreneur) to be higher in independence-oriented ventures than for growth-oriented ventures, other things being equal. Salary-substitute new ventures provide the psychological benefit of being one's one boss without the offsetting psychological costs associated with being the boss of a larger and more complex growth-oriented firm. Lifestyle ventures might be expected to provide significant beneficial psychological outcomes because the entrepreneur is dealing with customers and suppliers who share the same passion for the product or service, and thus myriad opportunities for pleasurable interaction and discussion are likely to arise. Lifestyle entrepreneurs are likely to identify strongly with their customers' needs and preferences and to want to interact congenially with these customers by best serving their needs. Further, since the independence-oriented entrepreneur is not seeking outright profit maximization, he/she can trade-off profit for psychological outcomes by allocating limited time to seek out and enjoy the company of people both within and outside the work environment.

Growth-oriented new ventures are less likely to provide these relatedness outcomes, and the time-constrained growth-oriented entrepreneur will likely need to sacrifice time-consuming personal interactions with employees, suppliers and customers in favor of using that time to pursue profit and growth opportunities. Growth ventures are also likely to be more complex 
organizations (Covin \& Slevin, 1997) with increasing numbers of employees, suppliers, and investors with whom to interact and relate. So although the quantity of stakeholders increases, the quality of interaction with this increasing array of stakeholders is likely to decline as the firm grows, and conversely the probability of friction with these stakeholders might be expected to increase with the size and the growth rate of the firm. This suggests the following hypotheses:

H3a: Preference for the work enjoyment will be negatively related to growth-oriented intentions;

H3b: Preference for the work enjoyment will be positively related to independenceoriented intentions.

\subsection{The Individual's Situational Need for Income}

Income is needed to compensate the individual for bearing risk and work effort, as detailed in the principal-agent literature and the finance literature more generally which argues that risk and return, and work effort and return, will tend to be positively correlated (see, e.g. Jensen \& Meckling, 1976; Fama, 1980). We expect that intending entrepreneurs will, in general, expect growth-oriented new ventures to provide higher personal income, other things being equal, as compared to independence-oriented new ventures. Growth ventures are likely to involve multiple rounds of investment (Morris et al. 2005), and such investment will not be undertaken unless the entrepreneur (and investors) expect sufficient income to be forthcoming to provide a competitive return on investment. As a prospective owner of a larger business the growth-intending individual will expect to gain higher dividend and perhaps also capital gains income from the sale of the business than he/she would as the prospective owner of an independence-oriented new venture, in both cases over some medium to longer term horizon. 
Independence-oriented new ventures, on the other hand, are characterized more by the provision of non-monetary as compared to monetary benefits, such that the (financial) return on investment is likely to be foreseen as relatively low, compared to growth-oriented new ventures. This suggests that independence-intending individuals may be happy to trade off income for the other four salient outcomes associated with their new venture. This suggests the following hypotheses:

H4a: Preference for income will be positively related to growth-oriented intentions;

H4b: Preference for income will be negatively related to independence-oriented intentions.

\subsection{The Individual's Situational Need for Risk Avoidance}

Now considering the individual's attitude to risk and the prospective new venture's provision of risky outcomes, we expect that growth-oriented new ventures will be expected (by the intending entrepreneur) to provide more-risky outcomes than would independence-oriented new ventures. This follows from our earlier analysis ranking the provision of income in the same order, since income and risk outcomes are commonly expected to co-vary positively. A further supporting rationale is provided by Shepherd, Douglas \& Shanley (2000) who argue that entrepreneurial risk is directly related to the ignorance of customers (market risk), producers (production risk) and managers (management risk). Growth-oriented new ventures will be perceived as more risky in prospect, other things being equal, because the customer is potentially exposed to a more-novel new product or service, the producers are potentially exposed to new production methods, and the entrepreneur/manager is potentially exposed to a wider range of unknown outcomes. Independence-oriented new ventures, on the other hand, will be foreseen as less risky due to the lesser market risk and production risk commonly associated with starting a 
new venture in an existing product or service category, particularly in the lifestyle subcategory where the intending entrepreneur is likely to have strong knowledge of the relevant technology and the nuances of the consumers' demand for the product or service.

According to SDT individuals will choose a new venture that, other things being equal, provides risky outcomes (and compensating levels of expected incomes) that are congruent with the individual's situational need for risk avoidance and income. From the above discussion we expect that the growth-oriented intending entrepreneur will be more tolerant of risk in the expectation that bearing risk is necessary to gain access to more-profitable outcomes. Conversely, those who are less tolerant of risk are likely to choose independence-oriented new ventures because the perceived risk exposure is perceived to be less. We note that the need for risk avoidance can be operationalized as its converse, namely the degree of risk tolerance exhibited by the intending entrepreneur. Accordingly, we suggest:

H5a: Tolerance for risk will be positively related to growth-oriented intentions;

H5b: Tolerance for risk will be negatively related to independence-oriented intentions.

\subsection{The Individual's Situational Need for Work Avoidance}

Finally we consider the individual's situational need for work effort avoidance, or conversely their need for leisure. This need arises due to the limited physical and emotional stamina of human beings and the depletion of one's reserves of such stamina by the expenditure of work effort, which is defined as the time at work multiplied by the intensity of work (Rainey, 2001; Locke \& Latham, 2004). We argue here that the expectation of work effort required by a

new venture will be typically greater, other things being equal, for growth ventures than for 
independence-oriented new ventures. The growth-intending individual is likely to expect that he/she will need to provide additional work effort as necessary to increase profits and/or growth. Conversely, an independence-oriented new venture, where income is traded off for work enjoyment (rather than maximized), allows work effort to be moderated, rather than the individual feeling compelled to provide additional work effort in pursuit of additional profit and growth. For 'lifestyle' businesses, work effort is applied in a context that is more intrinsically appealing, and thus is likely to be more tolerable to the entrepreneur. Similar to the need for risk avoidance, we shall operationalize the need for work avoidance by its converse, the degree of work tolerance exhibited by the individual. This suggests:

H6a: Tolerance for work effort will be positively related to growth-oriented intentions;

H6b: Tolerance for work effort will be negatively related to independence-oriented intentions.

\section{EMPIRICAL ANALYSIS}

\subsection{Sample}

Our sample is 140 second-year MBA candidates taking the 'Entrepreneurship and Business Plan' course in an AACSB accredited Business School in Thailand. About half of the sample was fully-employed, taking their degree on a part-time basis, and all had at least three year's work experience, with an average age of 32 years. Survey waves were conducted during classes at 4-7 day intervals, with intervening weekends and other classes and events serving to reduce common method variance and other biases. Responses were linked across survey waves by a secret code known only to each respondent. A total of 118 respondents completed a conjoint experiment. Four were later eliminated for inconsistent ratings of the duplicate scenarios, and 
eight others were eliminated as they did not complete one of the other surveys, leaving a final sample of 106 persons (76\%). Mean scores were used to replace occasional missing data points.

\subsection{Method}

The first survey utilized De Noble et al.'s (1999) 23-item (Likert 1-5) scale to assess respondents' entrepreneurial self-efficacy. A follow-up survey collected demographic and other control variables from the sample. Third, a conjoint experiment (see Green \& Srinivasan, 1978; Shepherd \& Zacharakis, 1998; Douglas \& Shepherd 2002; Monsen, Patzelt \& Saxton, 2010) was undertaken to reveal respondents' attitudes to the five salient outcomes of new ventures. Each of the salient outcomes was set as 'high' or 'low' in 16 different 'employment scenarios'. The definitions of high and low were clearly specified (see Appendix A) on the cover sheet and in a verbal introduction, for each of the salient outcomes. Each scenario was repeated once, such that 32 scenarios were presented to the sample in addition to an introductory scenario which they were 'walked through'. Four versions of the same instrument were utilized to avoid order effects - in two versions the order of the scenarios was reversed, and in the other two versions the order of the salient outcomes was reversed, and the four versions of the experiment were distributed at random. Respondents were asked to rate the 'attractiveness' to them of each scenario on a 7point Likert scale, where ' 1 ' related to 'highly unattractive' and ' 7 ' related to 'highly attractive'.

Finally, a survey comprising 20 new items was used to estimate each respondent's intention to start either a growth-oriented or an independence-oriented new business venture. Each item was preceded by the phrase asking "How likely is it that you would want to start a new business venture that" followed by a descriptive statement characterizing the prospective new venture in a particular way - see Table 2 for 13 items that were retained in the analysis. Respondents were 
asked to rate each of the scenarios on a 7-point scale, where ' 1 ' related to 'highly unlikely' and '7' related to 'highly likely'. Principal components analysis of these items was utilized to find factors corresponding to independence-intention and growth-intention, respectively.

Since demographic variables such as age, gender, prior education, and prior work experience have been shown to affect entrepreneurial intentions in previous studies (e.g. see Shane 2003, pp. 61-95), we included these as control variables.

\subsection{Results}

The means, standard deviations and inter-correlations for the variables are shown in Table 1. Prior work experience was removed from the analysis due to its high correlation with age. It is notable that the correlation between 'attitude to work enjoyment' and 'attitude to income' was significantly negative $(\mathrm{r}=-0.467)$. A scatter plot revealed that most of the respondents demonstrated relatively high scores on one and low scores on the other, indicating that respondents tended to trade off work enjoyment for income. Similarly, attitude to autonomy and attitude to work effort show a marginally significant negative correlation, indicating a tradeoff between these two variables as well, implying that individuals may be willing to work harder the stronger is their preference for autonomous decision making. Similarly, attitude to risk and attitude to work effort were marginally-significantly positively correlated, indicating that risk aversion and work aversion tend to go hand-in-hand, or alternatively that individuals are willing to work harder the stronger is their tolerance for risk.

\section{[Table 1 near here]}

Principal components analysis revealed that respondents' entrepreneurial intentions are 
separate and distinct as a two-factor solution. Oblique rotation was utilized as the two constructs are not orthogonal. As shown in Table 2, the first factor is an amalgam of eight items that indicates intention for independence-oriented entrepreneurship (Cronbach's alpha $=0.839$ ), and the second factor is an amalgam of five items that confirms a separate and distinct intention for growth-oriented entrepreneurship (Cronbach's alpha $=0.711$ ). Since the number of items retained in each factor differed, the average factor score for these items was utilized as our measure of the dependent variable in each of our two regression models.

[Table 2 near here]

The independent variables utilized in the regression analyses include the respondents' espoused entrepreneurial self-efficacy (ESE) measure, their revealed attitudes to the five salient outcomes of new ventures, and selected control variables. For ESE, a principal components analysis of the 23 items in De Noble et al.'s (1999) 23-item scale confirmed that all items loaded on a single factor, and thus the average factor score was used to measure the individual's ESE, as in De Noble et al., (1999).

For the attitude variables, a conjoint experiment was conducted to reveal the respondent's preferences for (or aversions to) each of the five salient outcomes. For each respondent there were 32 observations where the scenarios were rated on an 'attractiveness' scale of 1-7 according to the particular combination of salient outcomes in each scenario. A regression analysis was then performed to calculate the 'part-worths' of the utility function for each of the salient outcomes, for each respondent. The dependent variable in each of these 106 regression equations was the respondent's ratings of the scenarios presented. The five independent variables in each of these 106 regression equations were each dichotomous with ones representing 'high' 
and zeros representing 'low' on each of the five salient outcomes. This procedure generated utility part-worths for each of the salient outcomes of a career alternative for each respondent. These varied across respondents of course, but for interest's sake we show the descriptive statistics for the respondents' utility part-worths in Table 3.

[Table 3 near here]

We utilized Zellner's (1962) ‘Seemingly Unrelated Regression’ (SUR) analysis to estimate simultaneously the dependence of each of the two dependent variables (independence intention and growth intention) on the independent variables of ESE, five attitudes, and the control variables, using the STATA software package. The SUR method is appropriate when dependent variables are each regressed against a similar set of independent variables, since it minimizes the unexplained variance across the two regression equations. The results are shown in Table 4.

[Table 4 near here]

\section{DISCUSSION}

\subsection{Growth-oriented vs. Independence-oriented Intending Entrepreneurs}

We found a two-factor solution to entrepreneurial intentions, confirming that growthoriented intentions (GOI) and independence-oriented intentions (IOI) are separate constructs, and suggesting that prior measures of entrepreneurial intentions may have been too broadly defined. The antecedents for GOI and for IOI were found to differ significantly. While IOI were not well explained $\left(\mathrm{R}^{2}=0.094\right.$ with probability 0.28$)$ by the independent variables utilized, we found a significant negative relationship with risk tolerance $(p=0.033)$ and the relationship with 'attitude to autonomy' was not significant at the $10 \%$ level but was suggestive $(p=0.102)$. We 
also considered the influence of other variables on IOI, including prior income levels, prior entrepreneurship experience, parent self-employed, prior work experience (in place of age), and interaction effects between the attitudes and ESE variables (as suggested by Fitzsimmons and Douglas, 2011, and by Lee et al. 2011) but found no other significant determinants of IOI. This relatively poor showing for the IOI construct is probably attributable to the heterogeneity within the construct, including as it does an amalgam of salary-substitute, lifestyle and subsistence ventures (Barringer \& Ireland, 2006; Morris et al. 2005) who, while all broadly independenceoriented are probably trading off income in favor of autonomy, work enjoyment, and work effort, respectively.

The equation for GOI explained considerably more of the variance $\left(R^{2}=0.1554\right.$ with probability 0.026) and revealed a significant negative relationship with attitude to work enjoyment $(\mathrm{p}=0.035)$, a highly significant positive relationship with ESE $(\mathrm{p}=0.004)$, and a marginally significant positive relationship with being male $(\mathrm{p}=0.085)$. This result for sex resonates with other studies that found that female entrepreneurs are less likely than males to prefer growth outcomes (Cliff, 1998; Gundry \& Welsch, 2001; Cassar, 2006). Again we considered the influence of other variables on GOI, including prior income levels, prior entrepreneurship experience, parent self-employed, prior work experience (in place of age), and interaction effects between the attitudes and ESE variables, but found no other significant determinants of GOI. It would seem that ESE fully mediates the impact of many of these other independent variables on entrepreneurial intentions, as others have shown in the case of generic entrepreneurial intentions (e.g. Zhao et al. 2005). 
It is notable that while the control variables for age (negative and not significant for both equations), and prior business degree (positive and not significant for both equations), had the same signs for both GOI and IOI, the signs of the remaining independent variables were opposite for GOI as compared to IOI. ESE was negatively related to IOI but positively related to GOI, and being male was negatively related to IOI but positively related to GOI. Attitudes to work enjoyment, income and autonomy were positively related to IOI but negatively related to GOI, while both attitudes to work effort and to risk were negatively related to IOI but positively related to GOI. Although most of these were non-significant, the signs are generally in accord with our hypotheses, and these differences are highly suggestive. A replication of this study with other larger samples of intending entrepreneurs may reveal a greater number of significant relationships. Table 5 shows a summary of the hypotheses and the results.

[Table 5 near here]

Thus it may be that prior studies of (generic) entrepreneurial intentions suffered by the admixture of both growth-oriented and independence-oriented intending entrepreneurs in the same sample. Depending on the ratio of growth-oriented to independence-oriented individuals in the researcher's sample, the sign for most of the independent variables might potentially switch from positive to negative, or vice versa, and these might be significant or not. We particularly note that while attitude to risk has always been enigmatic in entrepreneurship research, we demonstrate that attitude to risk is unimportant for GOI but is highly (negatively) important for IOI. Similarly, ESE typically shows up as a significant determinant of generic entrepreneurial intentions, but we find that ESE is highly important for GOI but insignificant for IOI. It may be 
that ESE mediates attitude to risk for GOI, and perhaps ESE also mediates attitudes to income, autonomy and work effort for GOI. These are interesting questions for further research.

\subsection{Can we identify Intending entrepreneurs with a Predisposition for Growth?}

We believe that our research indicates that we may be able to distinguish between growthoriented intending entrepreneurs and independent-oriented intending entrepreneurs on four main grounds. First, GOI is strongly positively associated with ESE, whereas IOI is negatively but insignificantly associated with ESE. Thus intending entrepreneurs seeking public funding might be required to complete an appropriately validated ESE scale. Second, GOI has a significant negative association with attitude to work enjoyment, and we know from the significant negative correlation between attitude to work enjoyment and attitude to income that those with relatively weak attitudes to work enjoyment generally will have relatively strong attitudes to income. Another way to view this is that pursuit of work enjoyment in the workplace has an opportunity cost of the individual's time and attention, and thus serves to divert the entrepreneur away from the pursuit of profit and growth opportunities. This lack of concern for workplace enjoyment may be explained by the individual's focus on profit and growth outcomes, such that lost or foregone social relationships with individuals in the workplace are considered to be casualties of the battle to achieve higher profit and growth outcomes. Thus intending entrepreneurs seeking public funding might be required to complete an appropriately validated scale to discern their attitudes to work enjoyment and to income.

Third, IOI is significantly and negatively associated with attitude to risk, while GOI was not significantly associated with attitude to risk although it did have the hypothesized opposite sign. Thus intending entrepreneurs seeking public funding might be required to complete an 
appropriately validated scale to reveal their risk tolerance. Another possible indicator of IOI that was insignificant $(\mathrm{p}=0.102)$ in this study, and which had the opposite sign for GOI, is a positive attitude to autonomy. Desire to be one's own boss has long been considered a major motivation for entrepreneurship but this may be outweighed by negative aspects of business ownership in growth-oriented businesses. Again, intending entrepreneurs seeking public funding might be required to complete an appropriately validated scale to indicate their attitude to autonomy, particularly in a larger and growing firm with negative consequences of business ownership.

Finally, we found marginally significant evidence $(\mathrm{p}=0.085)$ of a positive relationship between GIO and the male sex, and an insignificant but negative relationship between IOI and the male sex. This is in line with previous studies (e.g. Cliff, 1998; Gundry \& Welsch, 2001; Cassar, 2006) who found that females were less likely to have growth aspirations than were males. We suspect that it is masculine traits rather than maleness (i.e. gender rather than sex) impacting GOI, such that it may be desirable to test for masculine traits in both men and women to gain an indication of the intending entrepreneur's predisposition for growth-oriented new ventures. Alternatively it may be that work-family balance issues and/or societal expectations and conditions present in the context of this study predispose men and women to form distinct intentions for business growth.

In summary, we can say that intending entrepreneurs with IOIs seem to be characterized by relatively low risk tolerance, and a (potentially significant) positive attitude to autonomy, while intending entrepreneurs with GOIs seem to be characterized by high ESE; negative attitude to work enjoyment, and being male (or masculine?). Thus we posit that public funding of nascent (and fledgling) entrepreneurs might be made conditional upon the scores of test items that 
investigate ESE; attitudes to risk, work enjoyment, income and autonomy; and the respondent's masculinity. No single indicator should be relied upon as a necessary or sufficient condition rather growth intention might arise from a 'fuzzy set' combination of the various drivers, just as it is a combination of the impacts of the human capital and attitudinal variables that determines whether self-employed is preferable to employment (Douglas \& Shepherd, 2000). Obviously the purpose of this survey instrument must not be transparent to the individual - if so, they might exhibit social desirability bias and/or attempt to 'game' the survey. To avoid this, the survey instrument must ask questions about a range of issues related and unrelated to entrepreneurship. For example, Lee et al. (2011) posed questions relating to job satisfaction in the context of the individual's prior (or current) employment roles and these items might be interspersed among a variety of questions relating to the innate psychological and situational needs, plus other items that might make the survey instrument seem to be focusing on a different main issue.

\subsection{Reconsidering the Definition of an Entrepreneur}

It is necessary in entrepreneurial research to clearly identify one's definition of the entrepreneur at the outset of a discourse in order to circumscribe what one means or does not mean by the term. Definitions range from 'anybody who starts a new business' to more selective definitions restricted to those who pursue growth-oriented new ventures. Perhaps the most popular textbook definition is that entrepreneurs are those who act to pursue the creation of new wealth, but by this definition the establishment of an independence-oriented new venture to engage in parallel competition using existing technologies within an existing product or service category may not qualify as entrepreneurship. For example, Barringer \& Ireland (2006; p.5) follow Stevenson (1983) and define entrepreneurs as "individuals (who) pursue opportunities 
without regard to resources they currently control" but subsequently (pp. 13-14) define three types of start-up firms, these being salary substitute, lifestyle, and entrepreneurial firms, thus excluding what we have collectively called 'independence-oriented' new ventures from their definition of entrepreneurial firms.

In the light of this it seems important to more clearly define (individual) entrepreneurship as the establishment of a new venture to pursue an opportunity that is expected to provide a combination of monetary and non-monetary (net) benefits that is superior to the best alternative employment opportunity, and within that definition acknowledge that some individuals will prefer to establish growth-oriented businesses while others will prefer to establish independenceoriented businesses. The creativity and innovativeness of the individual is a separate issue to the growth intention of the individual - thus some growth-oriented intending entrepreneurs will be more or less creative and innovative than others, and similarly some independence-oriented intending entrepreneurs will be more or less creative and innovative than others. Each of these variables, i.e. growth-orientation, independence-orientation, creativity and innovativeness, are likely to vary along a spectrum from relatively low to relatively high, reflecting the heterogeneity of nascent and practicing entrepreneurs.

\section{SUMMARY AND SUGGESTIONS FOR FURTHER RESEARCH}

In this paper we have examined the individual's intention to engage in entrepreneurial behavior from the perspective of the two main types of new ventures commonly observed. We investigated the intentions formation process and concluded that the intention to form a growthoriented or an independence-oriented new venture is embedded early in the intentions-formation process because the new venture chosen by the individual will be the result of the nexus of the 
individual's attitudes to the salient outcomes of the new venture and the new venture's provision of those salient outcomes. We argued that the intending entrepreneur will evaluate new venture opportunities in terms of five salient outcomes of new ventures and would expect a priori that growth-oriented and independence-oriented new ventures businesses would provide different quanta of these five salient outcomes. We developed scales that provided a two-factor solution indicating that growth-oriented intentions and independence-oriented intentions are separate and distinct constructs within the generic intention to start one's own business. We developed hypotheses relating to the expected sign and strength of relationship between growth-oriented intentions (GOI) or independence-oriented intentions (IOI) and the five salient outcomes, entrepreneurial self-efficacy (ESE), and the control variables of age, gender, and prior business (bachelors) degree.

To test these hypotheses, we first conducted principal components analysis on the results of a 20-item survey to find a two factor solution corresponding to GOI and IOI, with acceptable reliabilities, and used the average factor score of the five-item GIO factor and the eight-item IOI factor as the independent variables in the subsequent regression analysis. Attitudes to the five salient outcomes of career alternatives for each respondent were revealed via a conjoint experiment; ESE was estimated using a 23-item survey; and demographic and other control variables were collected via a separate survey. We found that IOI depends negatively (and significantly) on risk tolerance, and positively but insignificantly $(\mathrm{p}=0.102)$ on attitude to autonomy, while GIO depends positively (and highly significantly) on ESE, negatively (and highly significantly) on attitude to work enjoyment, and positively (and marginally significantly) on the individual being male. Moreover, the signs for GIO and IOI individuals were opposite for most of the above-mentioned independent variables. Although many of these relationships are 
not statistically significant in this study, it nonetheless seems possible to make a reliable 'firstcut' to discern growth-oriented individuals by measuring their ESE, their attitudes to work enjoyment (or conversely to income), risk, and autonomy, as well as testing for their masculine traits. A larger sample of actual intending entrepreneurs, particularly a longitudinal study of those who go on to launch and grow a business (on not), might validate or deny these findings.

\subsection{Contribution to the Literature}

This paper makes the following main contribution to the entrepreneurial intentions literature. First, it establishes that intentions for growth-oriented new ventures and for intentions for independence-oriented new ventures are separate and distinct constructs within the generic entrepreneurial intention construct and that prior studies potentially may have produced misleading empirical due to confounding the effects of the individual and the opportunity. Second, it establishes that antecedent entrepreneurial abilities and attitudes have a differential effect on entrepreneurial intentions according to the type of new venture envisioned. The previously enigmatic 'attitude to risk' as a determinant (or not) of entrepreneurial intentions now appears to relate only to IOI, not to GIO. High ESE relates only to GIO and is insignificant for IOI. Attitude to the non-monetary benefits of new venture ownership (work enjoyment), commonly supposed to be a strong driver of entrepreneurial intentions, is now seen to be viewed as non-significant for IOI individuals but is viewed as negative and highly significant by GIO individuals. Another strongly held assumption questioned by this study is that attitude to autonomy, while close to being marginally significant $(\mathrm{p}=0.125)$ for IOI individuals in this sample, is highly insignificant for those with GOIs. Third, this study serves to integrate into the literature of entrepreneurial intentions the individual-opportunity nexus and the utility- 
maximizing theory of entrepreneurial action. It also integrates first-person and third-person opportunities (McMullen \& Shepherd, 2006) by separating opportunity recognition from motivation to act entrepreneurially. Finally it suggests that growth-intentions, rather than generic intentions, should be the focus of policy makers interested in funding the start-up of new business ventures. This in turn suggests that a measure of 'growth-self-efficacy' might need to be developed rather than rely on generic measures of entrepreneurial self-efficacy, and that new measures of growth-intentions and measures of human, social, financial and technological capital should also be utilized.

\subsection{Limitations}

Of course this study has limitations. First, the results may not generalize to other samples. While the context and sample for this study (Thai MBA students) is interesting (Johns, 2006) and presents a useful divergent perspective outside the western context, the results refer to a specific subset of Thai society and may not generalize across Thais (due to socio-economic differences) or across MBA students in other cultures. A related issue is whether MBA students can reasonably be used as proxies for intending entrepreneurs. Shepherd \& DeTienne (2005) argue that they are an acceptable proxy, since they are at a 'crossroads of employment' where they might choose to start their own business venture in preference to seeking employment with an existing firm, and unlike undergraduate students, MBA students are substantially older and are likely to have a decade or more of business experience plus well-established business and social networks, and perhaps will also have better access to the funding required for new venture establishment. The alternative of course is to identify intending entrepreneurs by their own revelation, via 'cold-call' studies such as the 'PSED' (Reynolds, 2000) and similar surveys that 
identify nascent entrepreneurs (later in the intentions-formation process), but that approach is extremely expensive due to the low yield of nascent entrepreneurs secured. Although not ideal, we believe the use of MBA students in this study has value in that it has allowed us to find novel results that may be validated (or refuted) by future studies utilizing more-authentic data sources.

Another limitation is the low explanatory power of the regression equations. Clearly there are important missing variables that are not mediated by ESE, the salient attitudes, or the control variables we have included. But note that we did not set out to explain the entire variance surrounding GOI or IOI - our task was to ascertain whether GIO and IOI are differentially determined by the 'usual suspects' of intention analysis, viz: ESE, attitudes, age, gender, and so on. But for predictive purposes a higher degree of explained variance would be necessary, and predicting who will grow (or not) is what Shane (2009) has indeed called for. Thus more work needs to be done to develop more reliable survey items and scales for the independent variables identified here as critical differentiators, as well as on identifying other independent variables that are significant antecedents of GOI. We believe it is nonetheless a useful contribution to have identified the independent variables that do seem to explain a significant fraction of the variance surrounding GOI and IOI, and simultaneously to have demonstrated that some of the usual suspects do not significantly impact upon either or both of these intentions.

Following Shane's (2009) call for better-discriminating variables to more accurately identify growth-oriented entrepreneurs, we have identified four main variables that might be embedded into a survey instrument to be administered to intending-, nascent- or fledgling-entrepreneur applicants for public funding to support the establishment (or growth) of their business venture. We acknowledge that the design of this survey instrument must ensure that it is as free as 
possible from type 1 and type 2 errors, and that it is not so transparent to applicants that they would provide socially-acceptable answers rather than what they truly feel. Following crosssectional application of a suitably developed and validated instrument, longitudinal studies (e.g. Cassar, 2007) should follow the fortunes of publicly-funded firms to ascertain the predictive accuracy of the instrument being utilized and allow its subsequent refinement.

\subsection{Implications for Policy, Education and Further Research}

Public support for nascent and fledgling entrepreneurs includes their acceptance into 'technology incubators' where they are nurtured using at least some public funding. Such incubators often utilize 'eccentric' admission criteria that derive largely from the prior experience and beliefs of the incubator managers or their Board. We advocate that if the avowed mission of the incubator is to facilitate the successful growth of new ventures (or a similar performance metric) then they would be best served by applying admission and retention criteria that include the four main drivers of GOI that we have identified in this research.

Implications for practice may include inducing practicing entrepreneurs (who are ill-suited attitudinally to growth) to undertake further business education and/or attitude-modification training to build ESE, and increase their tolerance for risk. New business incubators may be able to significantly increase the growth-orientation of fledgling firms admitted by acting to enhance their ESE and to modify their attitudes during the time that the firms spend in the incubator.

Implications for entrepreneurship education include recognizing the main dichotomy between growth-oriented and independence-oriented entrepreneurship in our teaching of entrepreneurship, rather than preaching either a single simplistic definition or a variety of 
conflicting definitions of what constitutes entrepreneurship. Our discussions concerning the formation of entrepreneurial intentions need to consider the underlying cognitions, rather than treating intentions as a 'black box' that is somehow revealed by outward manifestations (such as cognitive style) or by subsequent actions. Our teaching may need to include (even more than it does already) attitude modification with regard to risk and work tolerance, and to emphasize that the pursuit of work enjoyment in the workplace may be complementary to, rather than in competition with, the pursuit of profit and growth opportunities.

There are many implications for further research arising from this study. First, similar studies might be conducted in other contexts to determine whether or not the findings are generalizable. Second, future studies should attempt to refine the independent variable constructs and/or to discover other significant determinants of GOI and IOI, including mediating and moderating variables. Third, different self-efficacy scales might be developed for different types of entrepreneurial new venture, to reflect more accurately the different tasks associated with the different types of new venture, rather than using a generic ESE measure as in previous studies. Fourth, future research might examine the subsistence, lifestyle and salary-substitution subcategories of independence-oriented new ventures, to ascertain whether these depend differentially on the underlying antecedent independent variables. Fifth, the 'growth aspirations' literature should be linked with growth intentions studies of individual in longitudinal studies that follow entrepreneurs over time to ascertain whether aspirations increase or diminish over time and in response to business circumstances. Growth-oriented entrepreneurs may revert to independence-oriented as time passes (see Dutta \& Thornhill, 2008). Finally, the opposite situation, where an independence-oriented entrepreneur 'strikes gold' and changes to become growth-oriented, suggests an interesting extension of the entrepreneurship literature. 
Table 1: Descriptive Statistics and Inter-correlations

\begin{tabular}{|c|c|c|c|c|c|c|c|c|c|c|c|c|c|c|}
\hline Variable & Mean & $\begin{array}{l}\text { Std } \\
\text { dev }\end{array}$ & 1 & 2 & 3 & 4 & 5 & 6 & 7 & 8 & 9 & 10 & 11 & 12 \\
\hline $\begin{array}{l}\text { 1.Independence } \\
\text { intentions }\end{array}$ & 5.4646 & 0.8911 & 1 & & & & & & & & & & & \\
\hline \begin{tabular}{|l} 
2. Growth \\
intentions
\end{tabular} & 4.5868 & 1.0086 & $\begin{array}{l}0.175 \\
* \\
\end{array}$ & 1 & & & & & & & & & & \\
\hline $\begin{array}{l}\text { 3. Attitude to } \\
\text { work enjoymt }\end{array}$ & 1.4472 & 0.7788 & 0.129 & $\begin{array}{l}-0.162 \\
*\end{array}$ & 1 & & & & & & & & & \\
\hline $\begin{array}{l}\text { 4. Attitude to } \\
\text { Income }\end{array}$ & 2.4407 & 0.8037 & $\begin{array}{l}-0.091 \\
\end{array}$ & 0.081 & $\begin{array}{l}-0.467 \\
* * *\end{array}$ & 1 & & & & & & & & \\
\hline $\begin{array}{l}\text { 5. Attitude to } \\
\text { work effort }\end{array}$ & -0.1972 & 0.5183 & -0.042 & 0.127 & 0.014 & 0.034 & 1 & & & & & & & \\
\hline $\begin{array}{l}\text { 6. Attitude to } \\
\text { autonomy }\end{array}$ & 0.7053 & 0.4892 & 0.095 & 0.082 & 0.060 & $\begin{array}{c}-0.243 \\
* * \\
\end{array}$ & $\begin{array}{l}0.167 \\
*\end{array}$ & 1 & & & & & & \\
\hline $\begin{array}{l}\text { 7. Attitude to } \\
\text { risk }\end{array}$ & -0.4525 & 0.5421 & $\begin{array}{l}-0.176 \\
*\end{array}$ & 0.106 & 0.103 & 0.079 & $\begin{array}{l}0.164 \\
* \\
\end{array}$ & 0.155 & 1 & & & & & \\
\hline 8. Age & 30.113 & 6.6709 & -0.124 & 0.026 & $\begin{array}{l}-0.193 \\
* * \\
\end{array}$ & -0.010 & 0.060 & 0.126 & 0.006 & 1 & & & & \\
\hline 9. Male & 0.5189 & 0.5020 & -0.092 & 0.149 & 0.011 & 0.004 & -0.014 & 0.150 & -0.016 & 0.082 & 1 & & & \\
\hline $\begin{array}{l}\text { 10. Prior degree } \\
\text { in business }\end{array}$ & 0.4623 & 0.5009 & 0.093 & 0.054 & 0.017 & $\begin{array}{l}-0.097 \\
\end{array}$ & 0.025 & -0.069 & -0.125 & $\begin{array}{l}-0.198 \\
* *\end{array}$ & $\begin{array}{l}-0.205 \\
* *\end{array}$ & 1 & & \\
\hline $\begin{array}{c}11 . \text { Prior work } \\
\text { experience }\end{array}$ & 6.3181 & 6.3023 & -0.086 & 0.091 & $\begin{array}{l}-0.188 \\
* \\
\end{array}$ & -0.069 & 0.080 & 0.158 & 0.011 & $\begin{array}{c}0.957 \\
* * *\end{array}$ & 0.100 & -0.122 & 1 & \\
\hline 12. ESE & 3.6812 & 0.4157 & -0.018 & $\begin{array}{l}0.259 \\
* * *\end{array}$ & 0.062 & $\begin{array}{l}0.007 \\
*\end{array}$ & 0.096 & $\begin{array}{l}0.182 \\
*\end{array}$ & 0.019 & $\begin{array}{l}0.214 \\
* * \\
\end{array}$ & 0.078 & -0.032 & $\begin{array}{l}0.205 \\
* *\end{array}$ & 1 \\
\hline
\end{tabular}

$* \mathrm{P}<0.10 ; * * \mathrm{P}<0.05 ; * * * \mathrm{P}<0.01 ; \mathrm{n}=106$

Table 2: Principle Components Analysis (with oblique promax rotation).

\begin{tabular}{|l|c|c|}
\hline How likely is it that you would want to start a new business venture that: & $\begin{array}{c}\text { Factor 1 } \\
\text { (Independence) }\end{array}$ & $\begin{array}{c}\text { Factor 2 } \\
\text { (Growth) }\end{array}$ \\
\hline $\begin{array}{l}\text { 1. Exploits a new technology that promises to have very good prospects for } \\
\text { long term growth and eventual profitability }\end{array}$ & 0.6036 \\
\hline $\begin{array}{l}\text { 3. Allows you to spend plenty of time away from work at rest or undertaking } \\
\text { recreational activities? }\end{array}$ & 0.6332 \\
\hline $\begin{array}{l}\text { 4. Allows you to earn enough money by doing the things that you like to do } \\
\text { best }\end{array}$ & 0.5965 & 0.6193 \\
\hline $\begin{array}{l}\text { 7. Is based on the gamble that a particular change in the laws will happen, and } \\
\text { that you will therefore be in a position to capitalize on that change? }\end{array}$ & & \\
\hline $\begin{array}{l}\text { 8. Focuses on a recreational other pastime that you really enjoy being } \\
\text { involved in? }\end{array}$ & 0.5980 \\
\hline $\begin{array}{l}\text { 9. Will not be very profitable at first, requiring several rounds of external } \\
\text { funding as it grows, before it eventually becomes highly profitable? }\end{array}$ & 0.5297 \\
\hline $\begin{array}{l}\text { 11. Involves a high risk of failure, but is expected to be extremely profitable } \\
\text { quite quickly if it takes off }\end{array}$ & & \\
\hline $\begin{array}{l}\text { 12. Does not require you work long hours every day, such that you can spend } \\
\text { plenty of time at home and/or taking part in social activities }\end{array}$ & 0.6894 \\
\hline $\begin{array}{l}\text { 15. Does not require you to work at high levels of intensity, which might } \\
\text { cause fatigue, stress, and other undesirable effects }\end{array}$ & 0.5466 & \\
\hline $\begin{array}{l}\text { 16. Capitalizes on your knowledge and enthusiasm for a particular hobby, } \\
\text { sport, or other recreational pastime that you really enjoy doing }\end{array}$ & 0.6245 & \\
\hline $\begin{array}{l}\text { 17. Allows you to close the business and take time off, or holidays, whenever } \\
\text { you choose }\end{array}$ & 0.7237 & \\
\hline
\end{tabular}




\begin{tabular}{|l|c|c|}
\hline $\begin{array}{l}\text { 18. Allows you to work at a job that is more like 'play' than work, since you } \\
\text { really enjoy the type of work that you would be doing? }\end{array}$ & 0.6582 & \\
\hline $\begin{array}{l}\text { 19. Will slowly build up sales and eventually becomes a very large business } \\
\text { with potentially thousands of employees spread around the world }\end{array}$ & & 0.4985 \\
\hline Cronbach alpha & 0.8385 & 0.7105 \\
\hline Proportion of Variance & 0.6865 & 0.3738 \\
\hline
\end{tabular}

(Loadings $<0.4$ are not shown)

Table 3: Sample 'utility part-worths' revealed by the conjoint experiment

\begin{tabular}{|l|c|c|}
\hline & Average & Standard Deviation \\
\hline Constant & 1.1887 & 0.9314 \\
\hline Income & 1.4116 & 0.7720 \\
\hline Work enjoyment & 2.4205 & 0.7977 \\
\hline Work effort & -0.2051 & 0.5188 \\
\hline Independence & 0.7155 & 0.5003 \\
\hline Risk & -0.4216 & 0.5496 \\
\hline
\end{tabular}

Table 4: Seemingly Unrelated Regression results for the two models

\begin{tabular}{|l|l|l|l|l|}
\hline & $\begin{array}{l}\text { Independence- } \\
\text { oriented model }\end{array}$ & & $\begin{array}{l}\text { Growth- } \\
\text { oriented model }\end{array}$ & \\
\hline & Coefficient & Probability & Coefficient & Probability \\
\hline Constant & 5.352 & $0.000^{* * *}$ & 2.9343 & $0.004^{* * *}$ \\
\hline ESE & -0.04476 & 0.966 & 0.6551 & $0.004^{* * *}$ \\
\hline Attitude - Work enjoyment & 0.1617 & 0.202 & -0.2926 & $0.035^{* *}$ \\
& & & & \\
\hline Attitude - Income & -0.0405 & 0.745 & 0.0406 & 0.765 \\
\hline Attitude - Work effort & -0.0586 & 0.721 & 0.1743 & 0.332 \\
\hline Attitude - Autonomy & 0.3042 & 0.102 & -0.0089 & 0.965 \\
\hline Attitude - Risk & -0.3429 & $0.033^{* *}$ & 0.2362 & 0.178 \\
\hline Age & -0.01239 & 0.356 & -0.0114 & 0.436 \\
\hline Gender (1= Male) & -0.1860 & 0.276 & 0.3219 & $0.085^{*}$ \\
\hline Prior Business degree & 0.0711 & 0.684 & 0.1895 & 0.320 \\
\hline " $R=s q$ " & & 0.0938 & & 0.1554 \\
\hline$R M S E$ & & 0.8871 & & 0.9694 \\
\hline Probability & & 0.2854 & & $0.0260^{* *}$ \\
\hline
\end{tabular}

$* \mathrm{P}<0.10 ; * * \mathrm{P}<0.05 ; * * * \mathrm{P}<0.01 ; \mathrm{n}=106$ 
Table 5: Summary of Hypotheses and Results

\begin{tabular}{|c|c|c|c|}
\hline No. & Hypothesis & Supported? & Comment \\
\hline $1 \mathrm{a}$ & ESE will be positively related to GOI & Supported & $\begin{array}{l}\text { Highly significant positive relationship } \\
(p=0.004)\end{array}$ \\
\hline $1 \mathrm{~b}$ & ESE will be positively related to IOI & Not supported & $\begin{array}{l}\text { Negative coefficient, but not significant } \\
(p=0.966)\end{array}$ \\
\hline $1 \mathrm{c}$ & $\begin{array}{l}\text { ESE will be more positively related to GOI } \\
\text { (than to IOI) }\end{array}$ & Supported & $\begin{array}{l}\text { Positive and significant for GOI, } \\
\text { negative for IOI }\end{array}$ \\
\hline $2 \mathrm{a}$ & $\begin{array}{l}\text { Preference for autonomy will be positively } \\
\text { related to GOI }\end{array}$ & Not supported & $\begin{array}{l}\text { Negative coefficient, but not significant } \\
(p=0.965)\end{array}$ \\
\hline $2 b$ & $\begin{array}{l}\text { Preference for autonomy will be positively } \\
\text { related to IOI }\end{array}$ & Not supported & $\begin{array}{l}\text { Positive coefficient, but not significant } \\
(p=0.102)\end{array}$ \\
\hline $2 \mathrm{c}$ & $\begin{array}{l}\text { Preference for autonomy will be more } \\
\text { positively related to IOI (than to GOI). }\end{array}$ & Supported & $\begin{array}{l}\text { Positive coefficient for IOI, negative } \\
\text { coefficient for GIO. }\end{array}$ \\
\hline $3 a$ & $\begin{array}{l}\text { Preference for the work enjoyment will be } \\
\text { negatively related to GOI }\end{array}$ & Supported & $\begin{array}{l}\text { Highly significant negative relationship } \\
\text { found. }(p=0.035)\end{array}$ \\
\hline $3 b$ & $\begin{array}{l}\text { Preference for the work enjoyment } \\
\text { associated will be positively related to IOI }\end{array}$ & Not supported & $\begin{array}{l}\text { Positive coefficient but not significant } \\
(\mathrm{p}=0.202)\end{array}$ \\
\hline $4 \mathrm{a}$ & $\begin{array}{l}\text { Preference for income will be positively } \\
\text { related to GOI }\end{array}$ & Not supported & $\begin{array}{l}\text { Negative correlation, but not significant } \\
(p=0.765)\end{array}$ \\
\hline $4 \mathrm{~b}$ & $\begin{array}{l}\text { Preference for income will be negatively } \\
\text { related to IOI }\end{array}$ & Not supported & $\begin{array}{l}\text { Positive coefficient, but not significant } \\
(p=0.745)\end{array}$ \\
\hline $5 a$ & $\begin{array}{l}\text { Tolerance for risk will be positively related } \\
\text { to GOI }\end{array}$ & Not supported & $\begin{array}{l}\text { Positive coefficient, but not significant } \\
(p=0.178)\end{array}$ \\
\hline $5 b$ & $\begin{array}{l}\text { Tolerance for risk will be negatively } \\
\text { related to IOI }\end{array}$ & Supported & $\begin{array}{l}\text { Significant negative relationship } \\
(\mathrm{p}=0.033)\end{array}$ \\
\hline $6 a$ & $\begin{array}{l}\text { Tolerance for work effort will be } \\
\text { positively related to GOI }\end{array}$ & Not supported & $\begin{array}{l}\text { Positive sign, but not significant } \\
(p=0.332)\end{array}$ \\
\hline $6 \mathrm{~b}$ & $\begin{array}{l}\text { Tolerance for work effort will be } \\
\text { negatively related to IOI }\end{array}$ & Not supported & $\begin{array}{l}\text { Negative sign, but not significant } \\
(p=0.721)\end{array}$ \\
\hline
\end{tabular}




\section{REFERENCES}

Ajzen, I. 1985. From intentions to actions: A theory of planned behavior. In J.Kuhl \& J. Beckmann (Eds.), Action-control: From cognition to behavior, pp. 11-39. Heidelberg: Springer.

Ardichvili, A., Cardozo, R. \& Ray, S. 2003. A theory of entrepreneurial opportunity identification and development. Journal of Business Venturing, 18: 105-123.

Bandura, A. 1977. Self-efficacy: Toward a unifying theory of behavioral change. Psychological Review, 84: 191-215.

Barringer, B. R. \& Ireland, R. D. 2006. Entrepreneurship: Successfully launching new ventures. Upper Saddle River, NJ: Pearson Prentice Hall.

Baumol, W.J. (1990) Entrepreneurship: Productive, unproductive, and destructive. Journal of Political Economy, 98(5), 893-921.

Birch, D.L. 1981. Who creates jobs? The Public Interest, 65: 3-14.

Bird, B. (1988). Implementing entrepreneurial ideas: The case for intention. Academy of Management Review, 13(3): 442-453.

Bird, B., \& Jelinek, M. (1988). The operation of entrepreneurial intentions. Entrepreneurial Theory and Practice, Winter, 21-29.

Boyd, N. \& Vozikis, G. S. 1994. The influence of self-efficacy on the development of entrepreneurial intentions and actions. Entrepreneurship Theory \& Practice, 18: 63-77.

Brigham, K., Shepherd, D.A. \& De Castro, J.O. 2007. A person-organization fit model of ownermanagers" cognitive style and organizational demands. Entrepreneurial Theory and Practice, 31: 2951.

Brockhaus, R.H. 1980. The effect of job dissatisfaction on the decision to start a business. Journal of Small Business Management, 18: 37-43.

Busenitz, L.W. \& Barney, J.B.1997. Differences between entrepreneurs and managers in large organizations: Biases and heuristics in strategic decision-making. Journal of Business Venturing, 12, 9-30.

Cassar, G. 2006. Entrepreneur opportunity costs and intended venture growth. Journal of Business Venturing, 21: 610-632

Cassar, G. 2007. Money, money, money? A longitudinal investigation of entrepreneur career reasons, growth preferences, and achieved growth. Entrepreneurship and Regioinal Development, 19: 89-107.

Chen, C. C., Greene, P. G. \& Crick, A. 1998. Does entrepreneurial self-efficacy distinguish entrepreneurs from managers? Journal of Business Venturing, 13: 295-316.

Choi, Y.R. \& Shepherd, D.A. 2004. Entrepreneurs' decisions to exploit opportunities, Journal of Management, 30(3); 377-395

Cliff, J. 1998. Does one size fit all? Exploring the relationship between attitudes to growth, gender and business size. Journal of Business Venturing, 13: 523-542.

Covin, J. \& Slevin, D. 1997. High growth transitions: Theoretical perspectives and suggested directions, in Sexton, D.L. \& Smilor, R.W. (eds), Entrepreneurship 2000, Upstart, Chicago, IL., 99-126.

Davidsson, P. 1989. Entrepreneurship and after? A study of growth willingness in small firms. Journal of Business Venturing, 4: 211-226.

Davidsson, P. \& Honig, B. 2003. The role of social and human capital among nascent entrepreneurs. Journal of Business Venturing, 18(3): 301-331.

Davidsson, P., Steffens, P. \& Fitzsimmons, J.R. (2008) Growing profitable or growing from profits: Putting the horse in front of the cart? Journal of Business Venturing, 24(4): 388-406.

Davidsson, P. \& Wiklund, J. 2001. Levels of analysis in entrepreneurship research: current research practice and suggestions for the future. Entrepreneurship Theory and Practice, 25(4): 81-100.

Deci, E.L. \& Ryan, R.M. 1985. Intrinsic motivation and self-determination in human behavior. New York: Plenum. 
Deci, E.L. \& Ryan, R.M. 2000. The "what" and "why" of goal pursuits: Human needs and the selfdetermination of behavior. Psychological Enquiry, 11(4): 227-268

De Noble, A., Jung, D. \& Ehrlich, S. 1999. Entrepreneurial self-efficacy: The development of a measure and its relationship to entrepreneurial action. Frontiers of Entrepreneurship Research, 73-87.

Douglas, E. J., \& Shepherd, D. A. (2000). Entrepreneurship as a utility-maximizing response. Journal of Business Venturing, 15 (3), 231-251.

Douglas, E. J. \& Shepherd, D. A. (2002). Self-employment as a career choice: attitudes, entrepreneurial intentions and utility maximization. Entrepreneurial Theory and Practice, Spring, 81-90.

Dutta, D. \& Thornhill, S. 2008. The evolution of growth intentions: Towards a cognition-based model. Journal of Business Venturing, 23: 307-332.

Eisenhauer, J. G. 1995. The entrepreneurial decision: Economic theory and empirical evidence. Entrepreneurial Theory and Practice, Summer: 67-79.

Fama, E.F. 1980. Agency problems and the theory of the firm. Journal of Political Economy, 88 (April), 272-84.

Fitzsimmons, J.R. \& Douglas, E.J. 2011. Interaction between feasibility and desirability in the formation of entrepreneurial intentions. Journal of Business Venturing, 26: 431-440.

Gagne, M. \& Deci, E.L. 2005. Self-determination theory and work motivation. Journal of Organizational Behavior, 26: 331-362.

Gartner, W.B., Shaver, K.G., Carter, N.M. \& Reynolds, P.D. 2004. Handbook of entrepreneurial dynamics: The process of business creation. Sage, Thousand Oaks, CA.

Green, P.E. \& Srinivasan, V. 1978. Conjoint analysis in consumer research: Issues and outlook. Journal of Consumer Research, 5, 103-123.

Gundry, L. \& Welsch, H. 2001. The ambitious entrepreneur: High growth strategies of women owned enterprises. Journal of Business Venturing, 16: 453-470.

Hessels, J., van Gelderin, M. \& Thurik, R. 2008. Entrepreneurial aspirations, motivations, and their drivers. Small Business Economics, 31: 323-339.

Jensen, M.C., \& Meckling, W.H. 1976. Theory of the firm: Managerial behavior, agency costs, and ownership structure. Journal of Financial Economics, 3, 305-360.

Johns, G.W. 2006. The essential impact of context on organizational behavior. Academy of Management Review, 31(2): 386-408.

Knockaert, M. Foo, M.D. \& Erikson, T. 2011. Determinants of entrepreneurs' growth intentions: A cognitive style perspective. Paper presented at the Babson College Entrepreneurial Research Conference, Syracuse, NY.

Kolvereid, L. 1992. Growth aspirations among Norwegian entrepreneurs. Journal of Business Venturing, 7: 209-222.

Kristof, A.L. 1996. Person-organization fit: An integrative review of its conceptualizations, measurement, and implications. Personnel Psychology, 49(1): 1-49.

Kristof-Brown, A.L., Ryan, D., Zimmerman, R.D. \& Johnson, E.C. 2005. Consequences of individuals' fit at work: A meta-analysis of person-job, person-organization, person-group, and person-supervisor fit. Personnel Psychology, 58(2); 281-342.

Krueger, N. 1993. The impact of prior entrepreneurial exposure on perceptions of new venture feasibility. Entrepreneurship Theory \& Practice, 18(1): 5-21.

Krueger, N. F. \& Brazeal, D. V. 1994. Entrepreneurial potential and potential entrepreneurs. Entrepreneurship Theory \& Practice (Spring): 91-104.

Krueger, N. F. \& Carsrud, A. L. 1993. Entrepreneurial intentions: Applying the theory of planned behavior. Entrepreneurship \& Regional Development, 5(4): 315-330.

Krueger, N.F. Reilly, M.D. \& Carsrud, A.L. 2000. Competing models of entrepreneurial intentions. Journal of Business Venturing, 15: 411-432.

Lange, T. (in press). Job satisfaction and self-employment: Autonomy or personality? Small Business Economics, published online 4 December 2009. 
Lee, L., Wong, P.K., Foo, M.D. and Leung, A. 2011. Entrepreneurial intentions: The influence of organizational and individual factors. Journal of Business Venturing, 26: 124-136.

Leung, A., Wong, P.K., Zhang, J. \& Foo, M.D. 2006. A multi-dimension of "fit" and the use of networks in human resource acquisition for entrepreneurial firms. Journal of Business Venturing, 21(5): 664686.

Linan, F. \& Chen, Y. 2009. Development and cross-cultural application of a specific instrument to measure entrepreneurial intentions. Entrepreneurship Theory and Practice, 33: 593-617.

Locke, E.A. \& Latham, G.P. 1990. A theory of goal setting and task performance. Englewood Cliffs, NJ: Prentice Hall.

Markman, G.D. \& Baron, R.A. 2003. Person-environment fit: Why some people are more successful as entrepreneurs than others. Human Resource Management Review, 13: 281-301.

McClelland, D. (1961). The achieving society. Princeton: D. Van Nostrand.

McGee, J.E., Peterson, M., Mueller, S. L., \& Sequeira, J. M. 2009. Entrepreneurial self-efficacy: Refining the easure. Entrepreneurship Theory \& Practice, 33: 965-988.

McMillan, L.H.W., O'Driscoll, M. P. and Burke, R.J. 2003. Workaholism: A review of theory, research, and future directions, International Review of Industrial and Organizational Psychology, 18: 167-189.

McMullen, J. S. \& Shepherd, D. A. 2006. Entrepreneurial action and the role of uncertainty in the theory of the entrepreneur. Academy of Management Review, 31(1): 132-152.

Monsen, E., Patzelt, H. \& Saxton, T. 2010. Beyond simple utility: Incentive design and tradeoffs for corporate employee-entrepreneurs. Entrepreneurship Theory \& Practice, 34(1): 105-130.

Morris, M., Schindehutte, M., \& Allen, J. 2005. The entrepreneur's business model: Toward a unified perspective. Journal of Business Research, 58(6): 726-735.

Palich, L.E. \& Bagby, D.R. 1995. Using cognitive theory to explain entrepreneurial risk-taking: Challenging conventional wisdom. Journal of Business Venturing, 10, 425-438.

Rainey, H. 2001. Work motivation. In R.T. Golembowski (ed)., Handbook of Organizational Behavior, 19-39. New York, Marcel Dekkar.

Reynolds, P.D. 2000. National panel study of US business startups: Background and methodology. In Advances in Entrepreneurship, Firm Emergence, and Growth. J.A. Katz (ed), JAI Press, Stamford CT., 4: 153-227.

Shane, S. 2000. Prior knowledge and the discovery of entrepreneurial opportunities. Organizational Science, 11(4): 448-469.

Shane, S. 2009. Why encouraging more people to become entrepreneurs is bad public policy. Small Business Economics, 33(2): 141-149.

Shane, S. \& Venkataraman, S. 2000. The promise of entrepreneurship as a field of research. Academy of Management Review, 26(1): 13-17.

Shaver, K.G., Gartner, W.B., Crosby, E., Bakalarova, K. \& Gatewood, E.J. (2001). Attributions about entrepreneurship: A framework and process for analyzing reasons for starting a business. Entrepreneurship Theory and Practice, 26(2): 5-33.

Shepherd, D. A. \& DeTienne, D. R. 2005. Prior knowledge, potential financial reward, and opportunity identification. Entrepreneurship Theory \& Practice (January): 91-112.

Shepherd, D.A., Douglas, E.J. \& Shanley, M. 2000. New venture survival: Ignorance, external shocks, and risk reduction strategies. Journal of Business Venturing, 15: 393-410

Shepherd, D.A. \& Zacharakis, A. 1998. Conjoint analysis: A new methodological approach for researching the decision policies of venture capitalists. Venture Capital, 1: 197-217.

Stevenson, H.H. 1983. A perspective on entrepreneurship, in Sahlman, W.A., Stevenson, H.H., Roberts, M.J. \& Bhide, A. The Entrepreneurial Venture, Harvard Business School Press, Boston, MA: 7-22.

Steers, R. M., Mowday, R. T., \& Shapiro, D. L. 2004. The Future of Work Motivation Theory. Academy of Management Review, 29(3): 379-387.

Storey, D.J. 1994. Small firm growth and bank financing. Small Business Economics, 6: 139-150. 
Suddaby, R. 2010. Construct clarity in theories of management and organization. Academy of Management Review, 35(3): 346-357.

Thomas, C.R. \& Maurice S.C. 2011. Managerial Economics: Foundations of Business Analysis and Strategy. McGraw-Hill Irwin, New York.

Thompson, E. R. 2009. Individual entrepreneurial intent: Construct clarification and development of an internationally reliable metric. Entrepreneurship Theory \& Practice, (May): 669-694.

Wennekers, S. \& Thurik, R. 1999. Linking entrepreneurship and economic growth. Small Business Economics, 13(1): 27-55.

Wiklund, J. \& Shepherd, D.A. 2003. Aspiring for and achieving growth: The moderating role of resources and opportunities. Jounral of Management Studies, 40: 1919-1941.

Zellner, A. 1962. An efficient method of estimating seemingly unrelated regression equations and tests for aggregation bias. Journal of the American Statistical Association, 57: 348-368.

Zhao, H., Seibert, S. E. \& Hills, G.E. 2005. The mediating role of self-efficacy in the development of entrepreneurial intentions. Journal of Applied Psychology, 90(6): 1265-1272.

Insert Charts 1 and 2 
Appendix A: Excerpt from Conjoint Experiment

\section{Please refer to these definitions as you complete the task.}

\section{Work Enjoyment}

$\underline{\text { High }}$ - Your personal enjoyment at work in the career option, due to factors such as interesting and challenging work, a sense of achievement, recognition for achievements, friendly and productive co-workers, etc will be relatively high.

Low - Your personal enjoyment at work in the career option, due to factors such as interesting and challenging work, a sense of achievement, recognition for achievements, friendly and productive co-workers, etc will be relatively low.

\section{Personal Income}

High- Total income is substantially above average for people your age, education and experience.

$\underline{\text { Low }}$ - Total income is substantially below average for people your age, education and experience.

\section{Work Effort Required}

High - Requires long hours per week and/or high intensity of work effort.

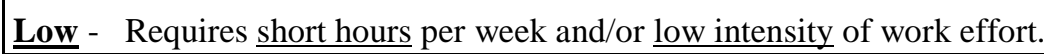

\section{Decision-making Autonomy}

High - You would be responsible for most decisions and not be highly constrained by the authority of others or by policies that apply to your actions.

Low - You would be responsible for very few decisions and would be highly constrained by the authority of others and by policies that apply to your actions.

\section{Risk}

High - There is a relatively high probability of losing your assets and/or suffering wide swings in your income level.

Low - There is a relatively low probability of losing your assets and/or suffering wide swings in your income level. 
Appendix B: Typical Scenario presented in the Conjoint Experiment

Please enter your confidential code*:

*First two letters of your Mother's name, plus the day of the month she was born. e.g. MA03

CAREER DXL

Work enjoyment -

Total expected income -

Hours/week and personal exertion -

Responsibilities and constraints -

Variability of income -
LOW Work Enjoyment

HIGH Income

LOW Work Effort

$\underline{\text { LOW Autonomy }}$

HIGH Risk

\section{Assessment: Attractiveness of this Career Option}

Based on the above career description (available within the two years of graduation and assuming you have accumulated savings equal to one year of salary), how would you rate the attractiveness of this career option? (Circle the number that best represents your response)

Very Low

Attractiveness

12
3

34
Very High

Attractiveness 